\title{
Entomophilous pollination in rape (Brassica napus L var oleifera) in Brazil
}

\author{
JEB Adegas ${ }^{1}, \mathrm{RH}$ Nogueira Couto $2^{*}$ \\ 1 Zootecnista Graduado pela Faculdade de Ciências Agrárias e Veterinárias, UNESP, São Paulo; \\ 2 Bióloga, Depto de Zootecnia de Não Ruminantes da Faculdade de Ciências Agrárias e Vete- \\ rinárias, UNESP, Rodovia Carlos Tonanni, 14870, Jaboticabal, São Paulo, Brazil
}

(Received 8 July 1991; accepted 15 December 1991)

\begin{abstract}
Summary - The present experiment was performed to study the development of rape flowers (Brassica napus var oleifera, cV CTC 4), volume and concentration of nectar produced, insects involved in the pollination and their behaviour in the flower (nectar or pollen collection), and the effects of this pollination on the production of pods and seeds, and germination and oil content in the seeds. The most frequent insect visitors to the flower were: Apis mellifera, $80.6 \%$; Trigona spinipes, $12.8 \%$ and Dialictus sp, $6.6 \%$. The sugar content averaged of $16.3 \mu \mathrm{g}$, and the percentage of sugar in the nectar collected from workers (Apis mellifera) was $37 \pm 18 \%$. Total protein content and ether extract in the pollen were 17.5 and $6.7 \%$, respectively. The visits of $A$ mellifera collecting nectar and pollen contributed to pollination and to an increased production of pods per square meter and individual seed weight. No influence was registered on total number of seeds per pod, normal seeds (fully formed) or abnormal seeds (shrivelled and undersized) per pod, percentage of seed germination and oil content.
\end{abstract}

Brassica napus var oleifera / pollination / nectar / foraging behaviour / Apis / Trigona / Dialictus / seed production

\section{INTRODUCTION}

Rape (Brassica napus) was cultivated in Japan 2000 years ago with seeds which had come from China. Rahman (1940), studying $B$ napus in India, concluded that bees Andrena ilerda Cam, Halictus sp, Apis florea $\mathrm{F}$ and Eristalis tenax $(\mathrm{L})$ were the main pollinating insects.

According to Jenkinson and Jones (1953), the presence of bees in the fields resulted in a production increase to $\mathbf{8 . 8}$ seeds per pod against 5.3 seeds per pod in bee-free fields, even though the connection between the anthers and the stig$\mathrm{ma}$ in individual flowers favors selfpollination.

Free and Nuttall (1968) noticed that the great majority of bees visiting the flowers collect nectar although some of them, mainly in the morning, collect pollen.

Williams (1985) reviewed the effects of honeybees and others insects on $B$ napus flowers and their foraging behaviour and

\footnotetext{
* Correspondence and reprints
} 
concluded that although swede rape is self-fertile, an external agent is important in transferring pollen from the anthers onto the stigma and the economic importance of the effect of bees on crop quality still needs to be established.

Having in view its recent introduction to Brazil as a possible fodder crop source or green manure (Granja, 1981), we conducted experiments and observations to study the development of rape flowers, the volume and concentration of its nectar, the insects involved in its pollination and their behaviour in the flowers (nectar or pollen collection), and the effects of pollination on the production of pods and seeds, germination, and content of oil in the seeds.

\section{MATERIAL AND METHODS}

The present work was performed at the Faculdade de Ciências Agrárias e Veterinárias de Jaboticabal, UNESP (Brazil), from June to October 1987 , on $92.5 \times 5.0 \mathrm{~m}$ plots of rape ( $B$ napus $L$ var oleifera, $c v C T C 4$ ), receiving 3 different treatments: $T_{1}$ covered with a nylon net with a colony of Apis mellifera: $\mathrm{T}_{2}$ only covered; and $T_{3}$ not covered. The experiment were carried out in a dark red median texture latosol (Aloisi and Dematté, 1974).

The main chemical characteristics of this soil were: $\mathrm{pH}\left(\mathrm{H}_{2} \mathrm{O}\right)=5.8 ; \mathrm{C}=1.14 \% ; \mathrm{Al}^{3+}, \mathrm{Ca}^{2+}$, $\mathrm{Mg}^{2+} \mathrm{e} \mathrm{H}^{+} ; 0.0 ; 3.6 ; 0.5$; and $3.6 \mathrm{e} \mathrm{mg} / 100 \mathrm{ml}$, respectively; $\mathrm{K}^{+}$and $\mathrm{P}\left(\mathrm{H}_{2} \mathrm{SO}_{4} 0.05 \mathrm{~N}\right)$ and $\mathrm{S}$ $\mathrm{SO}_{4}^{2}$ in the order, $158 \mu \mathrm{g} / \mathrm{ml} ; 10 \mu \mathrm{g} / \mathrm{ml}$; and 7 $\mathrm{ppm}$. The crop was established in lines $0.45 \mathrm{~m}$ apart using 7 seeds per linear meter.

The experimental site is located at an altitude of $595 \mathrm{~m}$ and the mean temperature of the region is $21^{\circ} \mathrm{C}$. The climate is subtropical with an average annual precipitation of $1431 \mathrm{~mm}$.

Throughout the whole flowering period, the cultures were kept under observation and the following aspects were studied:

- time of flower opening, time period up to wilting, and formation of mature pods (5 replications with 20 flowers per sampling);
- visiting insects in $T_{3}$. The most frequent visiting insects were collected and stored in alcohol for further identification;

- activities performed by visiting insect (pollen or nectar) and their frequency;

- frequency of visits per hour (7:00 to 18:00 h) determined weekly ( 5 weeks with 62 samplings). Numbers of pollen and nectar foragers were recorded on the plots uncaged and open pollinated for $10 \mathrm{~min}$ in each interval;

- time spent for pollen or nectar collection (121 replications);

- concentration of sugars in the nectar collected from $A$ mellifera workers by dissecting out honeystomachs at the following times: 8:00, 10:00, $12: 00,14: 00$ and $16: 00 \mathrm{~h}$ (4 replications);

- quantity of total soluble carbohydrates (average values- $\mu \mathrm{g} /$ flower) at 8:00, 10:00, 12:00, 14:00 and 18:00 $\mathrm{h}$ with 3 replications, according to the methodology described by Roberts (1977);

- number of seeds per pod for flowers visited only by $A$ mellifera but visited by different insects;

- number of pods originated from 50 flowers perforated by $T$ spinipes;

- total protein content and ethereal extract of pollen collected by $A$ mellifera during the foliate peak (AOAC, 1965), with 3 replicates.

The number of pods as well as the number of seeds per pod were also determined (100 replicates per treatment). The germination test, according to the rules for seed analysis (Brasil, 1976) was also performed in 4 replications, using 50 seeds/replication along with oil content determination in the seeds following the AOAC procedure (1965) with 3 replications, using $1 \mathrm{~g}$ of seeds/replication.

The data were analysed statistically by $F$ tests, and the means were compared by the Tukey test $(P<0.05)$.

\section{RESULTS AND DISCUSSION}

The flowering period extended for 35 days and the flowers remained open from 6:30 to $17: 30 \mathrm{~h}$. $B$ napus flower wilting started after an average time period of $32.5 \pm$ $8.6 \mathrm{~h}$ after the opening of the flowers. 
Insect visits to $B$ napus flowers reduced the duration of flower life and flowering. The absence of insects may induce some compensatory effect which improves production as reported by Mesquida et al (1988).

During the flowering period, the flowers were visited by $A$ mellifera, Dialictus sp, Dialictus phaedrus (Schorottky), Megachile (Ptilosarus) (Schorottky), Thectochlora a/aris (Vachal), and Trigona spinipes (Fabricius).

The species with the highest visit frequency was $A$ mellifera ( $80.6 \%$ ), followed by $T$ spinipes $(12.8 \%)$ and Dialictus sp $(6.6 \%)$.

The highest daily visit frequency was around 09:00 h for $A$ mellifera and 10:00 h for $T$ spinipes and Dialictus sp (fig 1). Free (1983) found that more pollen is collected in $B$ napus by $A$ mellifera between 08:0009:00 and 09:00-10:00 $\mathrm{h}$ on spring and winter rape, respectively. Free and Nuttall (1968) showed that the number of flowers visited per minute by honeybees ranges from 6.8-14.5.

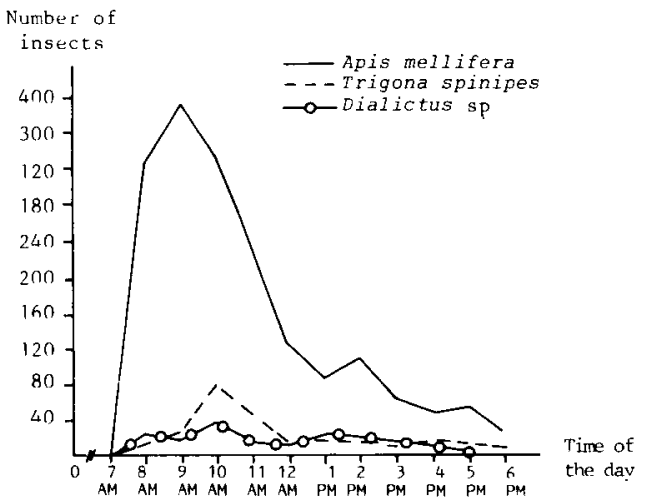

Fig 1. Frequency of Apis mellifera, Trigona spinipes and Dialictus sp in rape flowers during the day.
Regarding behaviour, it was observed that $A$ mellifera collected pollen and nectar in $T_{1}$ and $T_{3}$. The pollen collection was from 7:00 to 11:00 $\mathrm{h}$ and lasted an average time of $20 \pm 13 \mathrm{~s}$ for $T_{1}$ and $21 \pm 14 \mathrm{~s}$ in $T_{3}$.

Nectar collection was performed throughout the day, with bees staying on the flowers for an average of $3.2 \pm 0.2 \mathrm{~s}$ and $3.5 \pm 0.4 \mathrm{~s}$ for $T_{1}$ and $T_{3}$ respectively.

$T$ spinipes collected pollen exclusively, staying on the flower for an average of 52 $\pm 42 \mathrm{~s}$. This longer time was due to the fact that $T$ spinipes perforated the flower to collect pollen, reducing pod production by $86.0 \%$.

Dialictus $\mathrm{sp}$ collected pollen and nectar with an average visit time of $63 \pm 44 \mathrm{~s}$ and $8 \pm 10 \mathrm{~s}$, respectively.

The average time spent for pollen collection was 5-6 times longer than for the collection of nectar, consistent with the findings of Almeida (1985).

The concentration of sugars (4 repetitions per hour) in the nectar collected from A mellifera workers at 8:00, 10:00, 12:00, $14: 00$ and $16: 00 \mathrm{~h}$ was $36,37,34,33$ and $45 \%$, respectively.

The average concentration of sugars sampled from $A$ mellifera during foraging activity was $37 \pm 18 \%$, showing no significant differences $(P>0.05)$ throughout the day $(P>0.05)$. The quantity of sugars produced by the flower during the day averaged $16.3 \mu \mathrm{g} /$ flower. Davis et al (1986) studied Brassica napus $\mathrm{L}$ and found that the floral nectaries consist of 2 pairs of glands wich are supplied by phloem only. The lateral pair produces most of the nectar, whereas the median pair produces relatively little nectar. The nectar of $B$ napus (Regent) contained $38.7 \%$ sugar, with a sugar value (mg/flower/day) of 0.177 (Szabo, 1982). 
Total protein and ether extract in the pollen sampled from confined bee colonies was determined as $17.5 \%$ and $6.7 \%$, respectively.

The average number of pods per square meter, average weight of seeds (g), average number of seeds per pod, average number of normal seeds (fully formed) per pod, average number of abnormal seeds (shrivelled and undersized) per pod, and germination percentage are summarized in table I.

For the average number of pods, the results are the following: the production of pods in $T_{1}$ was higher when compared to $\mathrm{T}_{2}$. This was due to the pollination activity of the honeybees in the flowers. The increased production of pods by $T_{1}$ over $T_{3}$ was probably due to $T$ spinipes perforating the flowers in $T_{3}$.

Regarding the average weight of individual seeds, a significant difference among treatments was observed, since $T_{1}$ and $T_{3}$ produced heavier seeds than $T_{2}$
$(P<0.05)$. It was also noticed that the average number of seeds per pod in $T_{2}$ was greater than in $\mathrm{T}_{3}(P<0.05)$.

Plots visited by bees $\left(T_{1}\right.$ and $\left.T_{3}\right)$ contained fewer seeds/pods but heavier seeds than plots from which insects were excluded $(P<0.05)$. Jenkinson and Jones (1953) noted that when bees are present, plants produce fewer flowers and more seeds per pod.

Free and Nuttall (1968) found that although plots caged with bees produced more seeds, the seeds were smaller and weighed less than plots caged without bees.

Williams (1985) in a review on this subject verified that although caged plots have usually given lower or similar yields, sometimes yields have been greater. Williams et al (1987) explained the conflicting results regarding the effects of honeybees on seed yield of oil seed rape by the differences in growing conditions during seed production and concluded that plots

Table I. Number of pods, weight, and number of seeds with their percentage of germination. Average results in $T_{1}, T_{2}, T_{3}$.

\begin{tabular}{|c|c|c|c|c|c|c|c|}
\hline Treatments & $\begin{array}{l}\text { Average No } \\
\text { of pods } \\
/ m^{2}\end{array}$ & $\begin{array}{l}\text { Io Average } \\
\text { seed } \\
\text { weight (mg) }\end{array}$ & $\begin{array}{c}\text { Average No } \\
\text { of seeds } \\
\text { /pod }\end{array}$ & $\begin{array}{l}\text { Average } \\
\text { No of } \\
\text { normal } \\
\text { seeds } \\
\text { (fully- } \\
\text { formed) } \\
\text { lpod }\end{array}$ & $\begin{array}{l}\text { Average } \\
\text { No of } \\
\text { abnormal } \\
\text { seeds } \\
\text { (shrivelled } \\
\text { and undersized) } \\
\text { /pod }\end{array}$ & Seed & rmination \\
\hline$T_{1}$ & $798.84^{a}$ & $2.6^{\mathrm{a}}$ & $4.28^{\mathrm{ab}}$ & $3.74^{a}$ & $1.15^{\mathrm{a}}$ & $99.50^{\mathrm{a}}$ & $55.25^{\mathrm{a}}$ \\
\hline $\mathrm{T}_{2}$ & $308.19^{b}$ & $2.1^{b}$ & $4.46^{\mathrm{a}}$ & $3.92^{\mathrm{a}}$ & $1.32^{\mathrm{a}}$ & $98.00^{\mathrm{a}}$ & $53.75^{\mathrm{a}}$ \\
\hline$T_{3}$ & $539.57^{a b}$ & $2.6^{\mathrm{a}}$ & $4.19^{\mathrm{b}}$ & $3.66^{\mathrm{a}}$ & $1.36^{\mathrm{a}}$ & $97.75^{a}$ & $61.50^{\mathrm{a}}$ \\
\hline$F$ for treatmen & it $11.31^{*}$ & $18.72^{\star}$ & $5.10^{*}$ & $1.30^{\mathrm{NS}}$ & $0.68^{\mathrm{NS}}$ & $0.60^{\mathrm{NS}}$ & $1.98^{\mathrm{NS}}$ \\
\hline
\end{tabular}

Averages followed by same letters are not statistically different according to Tukey. NS: not significant; * significant at the $5 \%$ level; $T_{1}$ : netted with honeybees; $T_{2}$ : netted without honeybees; $T_{3}$ : open-pollinated. 
with honeybees produced pods containing more seed than those from plots without honeybees.

Barbier (1978) also reported that honeybee foraging activity produced greater numbers of seeds.

The average number of normal seeds per pod, the average number of abnormal seeds per pod and the percentage of germination showed no significant differences for $T_{1}, T_{2}$ or $T_{3}(P>0.05)$. The same was true for the oil content of seeds, which presented an overall average of $39.3 \% \pm 0.6$ $(P>0.05)$.

We conclude that $A$ mellifera was the main pollinating agent of rape (Brassica napus) during nectar and pollen collection. The second most frequent species on these flowers was $T$ spinipes, although it perforated flowers, and reduced pod production by $86 \%$. The Apis visits increased pod production and individual seed weight.

Moreover, in Brazil rape can be considered a high quality source of nectar and pollen for $A$ mellifera.

\section{ACKNOWLEDGMENTS}

We are very thankful to JM de Camargo for identifying the insects and to FAPESP for financial aid.

Résumé. - La pollinisation entomophile du colza (Brassica napus L var oleifera) au Brésil. L'expérimentation avait pour but d'étudier le développement des fleurs de colza (Brassica napus var oleifera, cv CTC 4), la production quantitative et qualitative de nectar, les insectes impliqués dans la pollinisation ainsi que leur comportement de butinage du pollen et du nectar et les effets de la pollinisation sur la production de siliques et de graines, la germi- nation et la teneur en huile des graines. Elle a eu lieu à $595 \mathrm{~m}$ d'altitude dans une région où la température moyenne est de $21^{\circ} \mathrm{C}$. Le climat est subtropical, les précipitations annuelles moyennes atteignent $1431 \mathrm{~mm}$. Chacun des 3 traitements $\left(T_{1}\right.$, filet en nylon + une colonie d'abeilles; $T_{2}$ : filet en nylon seul, $T_{3}:$ ni filet ni colonie) a été appliqué à 9 parcelles $(2,5 \times 5,0 \mathrm{~m})$ de colza. Les insectes les plus fréquents sur les fleurs ont été: Apis mellifera $(80,6 \%)$, Trigona spinipes $(12,8 \%)$ et Dialictus $\mathrm{sp}$ $(6,6 \%)$. Le maximum de visites se situait à $9 \mathrm{~h}$ pour $A$ mellifera et $10 \mathrm{~h}$ pour $T$ spinipes et Dialictus. La figure 1 donne la fréquence de ces insectes au cours de la journée sur les fleurs de colza. A mellifera et Dialictus ont récolté du pollen et du nectar sur les parcelles $T_{1}$ et $T_{3}$. $T$ spinipes n'a récolté du pollen qu'en perforant les fleurs, ce qui a réduit la production de siliques de $86,0 \%$. Le temps moyen passé était 5-6 fois plus long pour la récolte de pollen que pour la récolte de nectar. La concentration moyenne en sucres du nectar récolté par $A$ mellifera était de $37 \pm$ $18 \%$ et la quantité de sucres produite par fleur était en moyenne de $16,3 \mu \mathrm{g}$. Les pourcentages de protéines totales et d'extrait à l'éther des échantillons de pollen provenant des colonies d'abeilles confinées étaient respectivement de 17,5 et $6,7 \%$. Le tableau I donne le nombre moyen de siliques au $\mathrm{m}^{2}$, le poids moyen des graines $(\mathrm{g})$, le nombre moyen de graines par silique, le nombre moyen de graines normales (bien formées) et de graines anormales (ridées ou de taille réduite) par silique et le taux de germination. La production de siliques a été plus élevée avec $T_{1}$ qu'avec $T_{2}$. $T_{1}$ et $T_{3}$ ont produit des graines plus lourdes que $T_{2}$. Les divers traitements n'ont eu aucune influence sur le nombre total de graines par silique, sur le nombre de graines normales et anormales par silique, sur le taux de germination et sur le teneur en huite des graines. 
Brassica napus var oleifera / pollinisation / Apis / Trigona / Dialictus / comportement butinage / nectar / production de graines

Zusammenfassung. - Insektenbestäubung von Raps (Brassica napus var oleifera). Die vorliegenden Experimente wurden durchgeführt, um die Entwicklung. der Blüten des Raps (Brassica napus, var oleifera, cv CTC 4), Volumen and Konzentration des produzierten Nektars, die an der Bestäubung beteiligten Insekten und ihr Verhalten an den Blüten (Sammeln von Nektar und Pollen), den Effekt der Bestäubung auf die Erzeugung von Schoten und Samen, und die Keimung und den Ölgehalt der Samen zu studieren.

Das Versuchsfeld war in einer Höhe von $585 \mathrm{~m}$ gelegen, bei einer mittleren Jahrestemperatur von $21^{\circ} \mathrm{C}$. Das Klima ist subtropisch mit einer mittleren Niederschlagsmenge von $1431 \mathrm{~mm}$. Es wurden drei verschiedene Versuchsanordnungen angelegt, jede mit 9 Parzellen $(2,5 \times 5 \mathrm{~m})$ mit Raps: $T_{1}$, bedeckt mit Nylonnetz und versehen mit einem Bienenvolk; $T_{2}$, nur bedeckt, ohne Bienen; $T_{3}$, unbedeckt. Die häufigsten Blütenbesucher unter den Insekten waren: Apis mellifera $(80,6 \%)$, Trigona spinipes $(12,8 \%)$ und Dialictus $\mathrm{sp}$ $(6,8 \%)$. Für Honigbienen wurde die höchste Besuchsfrequenz um $9,00 \mathrm{~h}$ beobachtet, für $T$ spinipes und Dialictus $\mathrm{sp}$ um 10,00 h. Abbildung 1 zeigt die Häufigkeit dieser Bienen auf den Rapsblüten während des Tages. Es wurde beobachtet, daß A mellifera und Dialictus sp Pollen und Nektar in $T_{1}$ und $T_{3}$ sammelten. $T$ spinipes sammelte ausschließlich Pollen, wobei sie die Blüte durchbohrte; dadurch wurde die Erzeugung von Schoten um $86,0 \%$ reduziert. Die Zeit für das Pollensammeln war im Durchschnitt 5 bis 6 mal größer als für das Sammeln von Nektar.
Der Zuckergehalt der Blüten betrug im Durchschnitt 16,3 $\mu \mathrm{g}$ /Blüte, die Zuckerkonzentration des von Honigbienen während des Sammelns entnommenen Nektars 37 $\pm 18 \%$. Der Prozentsatz des Gesamtproteins und des Ätherextrakts von Pollen von im Flugkäfig gehaltenen Bienen betrug $17,5 \%$ bzw $6,7 \%$.

Mittlere Schotenzahl pro $\mathrm{m}^{2}$, mittleres Samengewicht (g), mittlere Samenzahl pro Schote, mittlere Zahl normaler (voll ausgeformter) Samen pro Schote, mittlere Zahl abnormer (geschrumpfter/zu kleiner) Samenkörner pro Schote und Prozentsatz der Keimung sind in Tabelle I zusammengefaßt. Im Vergleich zu $T_{2}$, war die Produktion von Schoten in $T_{1}$ höher. Die Versuche $T_{1}$ und $T_{3}$ lieferten schwerere Samenkörner als $T_{2}$. Kein Unterschied zwischen den Versuchsanordnungen wurde hinsichtlich der Gesamtzahl der Samen pro Schote, der Zahl normaler (voll ausgeformter) und abnormaler (geschrumpfter/zu kleiner) Samenkörner pro Schote, des Prozentsatzes der Samenkeimung und des Ölgehaltes gefunden.

\section{Raps / Nektar / Samenentwicklung / Apis / Trigona / Dialictus}

\section{REFERENCES}

Almeida LF (1985) Ensaio sobre polinizacão entomófila e tutoramento em Galactica striata (Jacq) Urb. Trabalho de Graduação, jaboticabal, FCAVJ, $33 p$

Aloisi RR, Dematte JLI (1974) Levantamento dos solos da Faculdade de Medicina Veterinãria e Agronomia de Jaboticabal. Cientifica 2, 123-136

AOAC (1965) Official Methods of Analysis of the Association of Analytical Chemistry. AOAC, Washington, p 937

Barbier E (1978) Pollinisation du colza par les abeilles. Rev Fr Apic 365, 288-291 
Brazil, Ministério da Agricultura (1976) In: Regras Para Análise de Sementes. DNPV Brazilia, $188 \mathrm{p}$

Davis AR, Peterson RL, Shuel RW (1986) Anatomy and vasculature of the floral nectaries of Brassica napus (Brassicaceae). Can J Bot $64,2508-2516$

Free JB (1983) Foraging behaviour of honeybees on oilseed rape. Bee World 64, 22-24

Free JB, Nuttall PM (1968) The pollination of oilseed rape (Brassica napus) and the behaviour of bees on the crop. J Agric Sci (Camb) 71, 91-94

Granja A (1981) Porto Alegre, RS, 37(398), 4748

Jenkinson JG, Jones GDG (1953) Observations on the pollination of oil rape (Brassica napus) and broccoli (Brassica oleracea). Bee World $34,173-177$

Mesquida J, Renard M, Pierre JS (1988) Rapeseed (Brassica napus $\mathrm{L}$ ) productivity: the ef- fect of honeybees (Apis mellifera $L$ ) and different pollination conditions in cage and field tests. Apidologie 19, 51-72

Rahman KA (1940) Insect pollination of toria (Brassica napus Linn var Dichotoma prain) and sarson ( $B$ campestris Linn var sarson prain) at Lyallpur. Indian J Agric Sci 10(3), 422-447

Roberts RB (1977) Method for assaying nectar sugar produced by plants and harvested by insects. J NY Entomol Soc 85(4), 197

Szabo TI (1982) Nectar secretion by 28 varieties and breeder's lines of two species of rapeseed. J Apic Res 122(9), 645-647

Williams IH (1985) The pollination of swede rape (Brassica napus $\mathrm{L}$ ). Bee World 66, 16-22

Williams IH, Martin AP, White RP (1987) The effect of insect pollination on plant development and seed production in winter oil-seed rape (Brassica napus L). J Agric Sci (Camb) 109, 135-139 